\title{
Ripley's Indictment of Corporate Skullduggery
}

DROFESSOR RIPLEY, the Harvard economist, in his book Main Street and Wall Street ${ }^{1}$ denounces the modern trend of corporate law and financiering. To the docile citizens who have invested their substance in the great corporations of this country, he cries: "Stop, Look and Listen!"

"Main Street" is the symbol for the phenomenon of widespread increase of popular investment in corporate stocks since the World War. "Wall Street" refers to the concentration of financial and directorial power in our great capital centers. The accusation is hurled by Ripley, the single-handed champion of "Main Street," against the Machiavellian wealth and power grabbers of "Wall Street," that by iniquitous newfangled clauses and inventions, inserted with devilish ingenuity in corporate charters, the doors have been thrown wide open to all sorts of financial shenamgan and jugglery. He describes this process by such terms as "prestidigitation, double shuffling, honeyfugling, hornswoggling and skullduggery!"

No wonder that, for a moment at least,
A look of sadness, a blush of shame,
Over the faces of Wall Street came,
A spirit of manhood within them stirred
To life at Ripley's horrible words.

The principal counts in the conspiracy indictment against the financiers and manipulators for the insidious undermining of the rights of the great body of shareholders and the attempted arrogation of uncontrolled power of dominion by the management or inside groups, may be enumerated as follows:

1. Limitation or abrogation of subscription or preemptive rights which protect shareholders against discrimination and the dilution of the value of their interests;

2. Waiver or release of hability of the management in case of wilful or negligent misconduct; waiver of disqualification of fiduciaries to vote or contract by reason of adverse interest;

3. Misuse of holding companies, particularly in the public utility field; juggling of accounts;

4. Abuses of no-par stock;

5. New issues of securities to the prejudice of prior issues; amendments taking away preferences of outstanding shares;

1 Mann Strees and WaIt Street. By William Z. Ripley. Boston: Little, Brown \& Company. 1927. pp. vii, 359 . 
6. Rape of the voting power, "the crowning infamy of all";

7. Withholding of information, which belongs to the corporation, for the private profit of those in control.

Some other minor charges may be briefiy dismissed. The "scandalous prostitution and laxity of the charter-mongering states," among which he refers to Delaware, Nevada, South Dakota, Maine, Arizona and others, is after all not such a crying public evil as he imagines. We ought indeed to be grateful to those states which have been progressive enough to work out liberal, flexible and practical corporation laws, which facilitate business by removing unreasonable restrictions. They are patronized by the most respectable and legitimate concerns.

The question of preemptive rights is, however, a difficuit and unsolved problem in corporation law and finance. The right is still indefinite in scope, and may hamper the management seriously in financial operations. It may interfere with underwriting arrangements to have to offer every new issue of shares first pro rata to existing shareholders. This is further complicated by the uncertain claims of different classes of shares. But it is a serious matter if there may be inserted waiver provisions giving unrestrained authorization to the management to dispose of shares at prices which will adversely affect the interests of existing shareholders as to control, dividend payments and capital distributions. By such provisions, if given full effect, discrimination might be allowed in the issue of shares and the increment in value might be diverted to those who are "in the know."

Articles of incorporation are treated by the courts as a contract entered into by all the shareholders, to which they freely consent. ${ }^{2}$ But in reality the articles are prepared by lawyers on instructions of promoters and prospective directors to give the management the widest possible scope of power, presumably to facilitate financing and the efficient conduct of the business. Various clauses are inserted which may operate as traps for the unwary investor, such as provisions that directors shall not be liable for negligence or misconduct in the performance of their duties. Professor Ripley justly contends that promoters and prospective directors should not be allowed to impose such foolish contracts on the shareholders by which they abdicate their rights and leave themselves in a position of utter helplessness. The new English Companies Act, 1928, expressly declares invalid such provisions.

Professor Ripley also does a service in warning investors that they

2 It is a business fact which should be recognized by the law that few persons buying stocks or bonds of corporations, or dealing with them as creditors examine their articles of incorporation. To examine the articles or hire a lawyer to do so whenever dealing with a corporation would be wholly impracticable. Yet the law now charges persons contracting with corporations with constructive notice of limitations and provisions of their articles or charters. 
should be on their guard against the attempted exemption of directors and officers from fiduciary liability in transactions in which they have an interest adverse to that of the corporation. ${ }^{3}$ Is it decent for directors to reserve full liberty to deal with themselves without disclosure? This "dastardly feature" is part of the "iniquitous tendency" which Professor Ripley finds toward an abridgement of the rights of the shareholders. As Berle ${ }^{4}$ says, there has as yet been no endeavor to work out corresponding limitations and checks on these tremendous powers of management against possible abuse, except such as may be afforded by courts of equity.

Professor Ripley is over severe in condemning the use of no-par shares as an "egregious malversation" of the rights of shareholders and of the public generally, and a substantial menace to sound corporation finance. He considers the device as "overflowing with possibilities of fraud and deception." More specifically, the objections are that there is a practical disappearance of any precisely defined capital fund, which increases "the possibilities of obfuscation, to say nothing of malfeasance." On the face of the statutes there seems often to be an apparently uncontrolled power in the directors to fix the price of each issue of shares, even to the prejudice of prior or subsequent holders. In effect, however, such power would be somewhat restrained by courts of equity and by commissioners of corporations in issuing their permits for security issues. A fiduciary duty on the part of those in control requires that new issues of stock be made "within a reasonable range of the best obtainable price." 5

Professor Ripley particularly objects to the capitalization of earning power or good will, which would seem to be a valid criticism only in the case of public utilities. While good will and earning power are assets for which the public is willing to pay, it may be admitted that no-par shares have aided the orgy of stock inflation which is incident to this era of consolidations and mergers, the profits on which have been nothing short of miraculous. The control of vast enterprises has been obtained by financial sorcerers who furnished little of the actual investment.

The culminating offense of all in this legal onslaught upon all the traditional safeguards of shareholders is their "disfranchisement." Nonvoting stock is a device which makes possible the concentration of the control of a vast enterprise in the hands of bankers or of some close management group. By abdicating their voting rights, shareholders

3 Probably all provisions in the articles would be held subject to the rule that the directors as fiduciary agents must at all times act in good faith and with reasonable diligence in the interest of the shareholders.

4 A. A. Berle, Studies in the Law of Corporation Finance (1928) $26 \mathrm{ff}$.

5 BERLE, op cit. 82, 139. 
become mere wards of chancery, so far as control over their own affairs is concerned. They are more and more in the position of creditors or lenders rather than of owners of the business. They invest their money in a discretionary obligation. The management is the corporation. It is no longer an association of shareholders. ${ }^{\circ}$

Professor Ripley moves a poet to cry:

"Oh drop a tear for those who own

Non-voting corporate stock."

It is rather naively assumed by Professor Ripley as a major premise that each shareholder is one of the owners or proprietors of the corpo. rate property. He objects violently to the divorce of ownership and control. He fails to perceive that the estate or interest of the shareholder is that of ownership only to the extent that the charter contract expressly or impliedly makes it so. His rights are as much derived from contract as those of the bondholder. The elements or incidents of ownership are spht up and subdivided among all the different classes of stock and bond holders. The duties of management are owed to the corporation for the benefit of these different beneficiaries according to their contracts. It has been sagely observed that "only God can make a tree, and only God can look after those who do not write their contracts as they should be written."

It has been estimated that something like 1630 varieties of preferred shares are possible. There is in general no legal limit to the classes or combinations of shares that may be provided for in the articles. The corporation may sell such relative rights or chances to participate in the enterprise as will appeal to the investing public. These may differ as to priority of claims on profits, participation, cumulation, dividend rates, conversion rights, voting rights, which may be full, qualified or contingent, preemptive rights, amounts payable on redemption, dissolution, liquidation, consolidation, merger or sale of entire assets, protection against amendments and mortgages or otherwise. In a few states there are constitutional and statutory provisions giving every shareholder the right to vote for directors, if not on other questions, and guaranteeing the right of cumulative voting. But in general as to the extent of rights and privileges given the shares, the doctrine of caveat emptor applies.

\footnotetext{
${ }^{6} A$ shareholder pays a certain price for rights to participate in the earnings and assets of the corporation. The shareholders' rights differ from the creditors' in that his right of participation is made speculative, and more or less contingent on the discretion of the management. He buys a certain assortment of rights stated in a contract, the articles, and pays what he thinks they are worth. He does not acquire "title" or "ownership" of the corporate property or business, even in equity. He does not become a principal. He is a kind of creditor and in a broad sense one of the beneficiaries of a discretionary trust. In general, parties in forming a corporation should be free to set up and assort their rights to suit their convenience.
} 
Investors must be on their guard and deal at arm's length in what they buy.

Professor Ripley admits that any expectation of general active participation by the whole body of shareholders in corporate management is doomed to disappointment. They have no inclination or capacity to share in the conduct of the business, or ordinarily even in the election of directors. What the shareholders do want is honest and efficient management and the largest possible dividends. You cannot have efficient management without giving very broad powers to the board of directors.

What is needed is something which will operate as a reasonable check or balance upon the sovereignty of management; something to stimulate the sense of trusteeship and responsibility on the part of those in supreme authority to the passive investors whom they are supposed to represent, but with whom they often deal at arms' length. Something may be accomplished by the recognition of a fiduciary obligation on the part of the "management stock" to exercise its control for the benefit of the entire body of stockholders who lhave no voice.

The question of concentrating control in a small class of management stock and leaving the bulk of the common stock without voting rights is a different question froin that of limiting the voting rights of preferred stock. The line we draw between the voting rights of bondholders or debenture holders and of preferred stockholders is largely a matter of tradition. Preferred shareholders and even bondholders ought, bowever, to have a voice at least in case of emergency such as nonpayment of dividends or interest. The preservation of contingent or limited voting rights should perhaps be left to the direct action of investors and to the influence of stock exchanges, investinent bankers and underwriting firms which often insist on adequate voting safeguards, rather than to positive rule of law. 8

The most valuable portion of Professor Ripley's polemic is directed to the shareholder's right to adequate information. The "limitless obfuscation" which results from the secretive tactics of many managements is vividly illustrated by the financial reports of some of the leading giants of Wall Street. The results of operation, the methods of valuation of assets, and the financial condition as to surplus, reserves and provisions for depreciation are often given ouly superficially, if at all, in a ridiculously attenuated annual report. The establishment of a fair

7 But see F. S. Wood, Voting Status of Management Stockholders (1928) 38 YACE L. J.57.

${ }^{8}$ Shareholders ordinarily have no wish to vote. They should be given the chance to do so in emergencies and upon organic changes in structure. There is no natural or inherent right to vote. 
market price for his securities consonant with the real earning power and financial condition of the company is of daily importance to every shareholder. Corporate officers and directors frequently profit by the undue depreciation or inflation of the stock of their corporation through inadequate reports and concern themselves with the stock-ticker rather than with building up the business. The corporation itself must be protected against imprudent and undue disclosure, but information as to corporate affairs belongs to the corporation for the profit of all the shareholders alike, and not to the officers alone. ${ }^{9}$

Shareholders are generally given a more or less useless and himited individual right of inspection of the corporate books, at least of the stock ledger. The exercise of this means of inquiry is satisfactory neither to the corporation nor to the shareholder. As Berle says, "A man with 5 or even with 500 shares simply cannot protect his position. It would cost him the entire value of his holding to attempt to do so." Professor Ripley points to the very unuch more satisfactory provisions of the English statutes for reports and for an independent audit. He suggests a "check-up committee," or a supervising board representing all the shareholders, which should have access to all the records and accounts, and should make an independent examination of corporate affairs at the expense of the corporate treasury.

The new English Companies Act of August, 1928, amending the Companies Acts, 1908 to 1917, adopted in pursuance of the report of the Company Law Amendment Committee, 1926, adds valuable provisions as to annual profit and loss accounts, balance sheets, auditors, investigation of the companies' affairs by inspectors, as well as provisions as to the hability of directors for negligence, and disclosure by directors of their interest in contracts, all tending to enforce responsibility in management. New corporate legislation as to disclosure and inquiry has been adopted recently in The Netherlands.

Corporation law and practice are undergoing a development that amounts to a quiet revolution; acute issues are raised as between power and efficiency of management on the one hand and the security of investors on the other; difficult probleins are presented which remain to be worked out and on which English and foreign legislation will shed much hight; to some of these problems Professor Ripley has succeeded in directing much needed public attention which may stimulate constructive efforts in the various states.

Hensy W. Ballantine.

SCHOOL OP JURISPRUDENCE, UNTVERSITY OF CAITFORNTA.

9 BERLE, op. cit. 176. 